DOI: 10.1515/ausp-2017-0008

\title{
Heterotopic Discourse in Ivo Andrić's The Damned Yard
}

\author{
Éva TOLDI \\ University of Novi Sad (Novi Sad, Serbia) \\ Department of Hungarian Studies \\ evatoldi@eunet.rs
}

\begin{abstract}
The paper analyzes Ivo Andrić's novel The Damned Yard, a work that has received continuous critical attention since its publication. Its interpretation presents a challenge even to the latest schools of literary theory. With a focus on the poetics of space, the argument applies Michel Foucault's theory and discusses the roles heterotopias play in structuring the narrative. Heterotopias reveal the attributes of real and metaphoric spaces, while the dynamics of space influence the movements of narration in the novel. Reproducing diverse forms of deviance, heterotopia delineates the frame of the individual's identity. The conclusion suggests that the text's complex metaphysical web of meanings is produced by the deranged identity appearing in a closed space, and the correspondingly deranged narration. ${ }^{1}$
\end{abstract}

Keywords: poetics of space, heterotopia, prison, identity, madness.

The volumes discussing the oeuvre of Nobel laureate Ivo Andrić could fill libraries. It is no exaggeration to claim that he is the author of Serbian literature who has been discussed most frequently and interpreted from the most diverse perspectives. His works were brought to literary limelight most recently in 2011, the fiftieth anniversary of his Nobel Prize, when his bibliography containing 15,647 items was published in the joint edition of the Belgrade Ivo Andrić Foundation, the Serbian Academy of Sciences and Arts, and the Matica Srpska Library of Novi Sad (Klevernić and Mirić et al. 2011). His works continue to kindle interest among interpreters, and in Serbia only, about five to six volumes related to his oeuvre are published yearly, part of which are republications of his previous works, while the number of article collections discussing his works is also significant.

1 The study was conducted within project no. 178017 of the Ministry of Science and Education of Serbia. 
Several of the works interpreting Andrić's texts are actualizing and referential, registering its parallels with the state of affairs within the region at the turn of the millennium, or more precisely, with what one could experience during the war in the territory of the former Yugoslavia. Such interpretations read the depictions of the past against present events with a characteristic, exclusively negative ideological bias, and they disregard the fact that "heritage (Bosnian Croat) and the chosen language of literary utterance (Serbian, as well as the national and regional dialects spoken by his characters) in themselves offer a unique basis for conceptual openness and the recognition of cultural diversity" (Thomka 2009, 55). ${ }^{2}$ Today, in the ideologically biased reading of Bosnian public discourse, the Nobel Prize winning novel, The Bridge on the Drina is the work that is targeted most by negative criticism, with the main accusation against it being that it puts Bosnians into a negative light, and thus serves as a foreshadowing of the war breaking out later. The author is declared a villain and a traitor, and it is suggested that if he were alive, he should face the international tribunal at The Hague for war crimes (Thomka 2009, 55). Milo Dor talks about a similar experience in his afterword to the German edition of The Damned Yard. He considers Ivo Andrić a socially dedicated writer who, instead of dealing with matters of daily politics, represented European values. Andrić was born into a Catholic family of Croatian descent in Bosnia, but lived in Belgrade, and wrote in Serbian, which in itself was enough to provoke the anger of Croatian politics and make his works disappear from school textbooks. Andrić's fate, however, was hardly more fortunate in Bosnia. He belonged to Yugoslav intellectuals who insisted on the country's European ties, despite its inner contradictions. In Dor's opinion this may have been the reason that his modest statue erected by the bridge in Višegrad was demolished by a "fanatic and mad Muslim," in retaliation for the horrific deeds the Serbian army had committed in the recent war (2002).

Much more important than the actualization of the texts in contemporary politics is another challenge faced by the interpreters. In line with the trends forming the literary, historical and critical discourse and its changes at the end of the twentieth century, the reception of Andrić acquired new dimensions, giving way to up-to-date interpretations and perspectives. His oeuvre, the multiethnic and multi-religious society, presented in a historical context, provides excellent material for the latest schools of literary theory, such as multiculturalism, postcolonialism, otherness studies or approaches informed by perspectives of gender or spatial studies.

Works dealing with Andrić frequently refer to the rich potential that his texts offer for analysis, as well as the large number of existing interpretations and their diversity. His reception suggests that one reading does not extinguish the other,

2 The translations from Hungarian and Serbian specialist literature are my own throughout the article. 
and experts agree that the call for newer and newer interpretations is coded in his texts. The characteristics of narration and the refined solutions in the structure of the texts allow for diverse modes of understanding.

Interpretations regularly allude to the importance of the "spatial" dimension of Andrić's texts, yet they are mostly concerned with their location. Thus the analyses often focus on Bosnia, the Balkans, the East-West dichotomy, their historical-referential as well as temporal aspects. Andrić's texts are characterized by the multifarious layers of the texts; the analyses of the layers show how versatile and universal aspects are built on operations of ascribing local meaning (Vukićević-Janković 2015). When I analyse The Damned Yard from the aspects of spatial poetics, I regard space crucial not only as the location of the narrative, but also in terms of identity construction. The spatial poetic aspect is a structure "above" the actual locality, and the analysis of the spatial arrangement/pattern highlights the complexity of the narration.

\section{The Text's Intergeneric Space}

The last extensive, finished work of the author, The Damned Yard, exemplifies the typical proliferation of the secondary literature dealing with Andrić: it is discussed in three bulky monographs (Džadžić 1975; Kostić 2006; Minić 1976), which cannot be regarded as customary even if we are aware that already at the point of its publication this work was considered the peak of the author's art, the dense formulation of his poetics, and this opinion has persisted to the present day. The novel is additionally unique in the sense that it is the one that took the most time for its author to write. Scholars researching his biography claim that seventeen years were required until the novel took its final form. Details of the novel's genealogy were revealed by the author himself. Bori tells us that "[h]e started writing between 1928-1929, on letterhead sheets of Madrid hotels, during the months of his diplomatic service, and returned working on the draft again in April 1952, finishing it in April 1954" (1992, 136). Philologists suggest that some versions of it were as long as two hundred and fifty manuscript pages, while the final version, which was published in 1954, was a result of some radical simplifications, left out several threads of the narrative, and resulted in a "highly condensed text” (Đukić Perišić 2012, 466).

Scholars are puzzled by the brevity and fragmentary character of the work. While they remind readers that the author did not refer to any of his works as novels, still, some regard the text as a short story, some say it is a novel or a novella, while others place it on the border between a short story and a novel. Some of the generic descriptions used refer to characteristics of the text, such as in saying that The Damned Yard is a "short-story-like novel," "a parabolic 
novel," "a metaphysical novel," "a novel of prison conversations," "a portrait novel," "a narrative about narration" (Bori 1992). Some of the interpreters find a sense of personal motivation, a biographical detail in the text, supposing that it contains an "authorial self-portrait," saying that the shared experience of Andrić and his hero, Fra Petar, "is possible to detect, but is not directly identifiable," namely that they both spent two months in Konstanz, imprisoned by the Gestapo. It is also taken as no accident that "Konstanz and the city of The Damned Yard were both named after the tyrannical emperor Constantine" (Márton 2007, 72). Most researchers, however, find the label "history" to be most proper, with the idea of the plot, the "story" emphasized in it.

The Damned Yard offers diverse criteria, and thus provides several options for arrangement. Additionally, its highly puzzling nature makes it impossible to opt for a single arrangement that would rule out the rest. In the following, I will put forth an argument that reads The Damned Yard as a spatial novel, anchoring its central motif in the notion of identity.

\section{The Spatial Delineation of the Locale}

The title of the novel offers itself for an interpretation focusing on space. The Damned Yard specifies the locale of the work, radicalizing space. Throughout the majority of the novel the narrator is a Bosnian Franciscan monk, Fra Petar, who remembers the two months he spent in a prison in Stamboul, called simply the Damned Yard by people.

Every culture, every civilization has its

real and effective places which are outlined in the very institution of society, but which constitute a sort of counter arrangement, of effectively realized utopia, in which all the real arrangements, all the other real arrangements that can be found within society, are at one and the same time represented, challenged, and overturned: a sort of place that lies outside all places and yet is actually localizable. (Foucault 1997, 332)

It is these spaces that Michel Foucault calls heterotopias.

The Damned Yard is a typical representation of a heterotopia. Within Foucault's heterotopology it may be labelled as a heterotopia of deviation, a location for "individuals whose behavior deviates from the current average or standard" (1997, 333). Such locations are rest homes, psychiatry clinics, prisons or oldpeople's homes.

The Damned Yard is a prison, but not of the usual sort. It is a transitory place where people are interrogated, where people serve their minor sentences; this is 
the place where they are sentenced to banishment or from where they are released in case they are proven not guilty. The yard does not comply with any norm. Its shape differs from the customary and is not characterized by strict order. The place is prehistoric chaos itself. "About fifteen buildings, some with two floors, built and extended over many years and linked by a high wall, enclose a huge, elongated, steep courtyard of irregular shape" (Andrić 2014a, 245).

Natural vegetation is almost completely missing from it, and if two or three trees are still to be found, these live a "martyred life" (Andrić 2014a, 245). "There are some cobbles in front of the building for the guards and administrative offices; all the rest is grey, hard trodden earth where not even a blade of grass succeeds even in sprouting, so many people walk over it from dawn to dusk" (Andrić 2014a, 245).

Fra Petar describes the Damned Yard several times. Its location is peculiar, and the perspective it offers is quaint. It is impossible to look out of the Damned Yard; the fact that there is a city outside, a port and the whole deserted arsenal by the sea exists only in the consciousness of the inhabitants. "Only the sky, vast and merciless in its beauty, in the distance a little of the green Asian shore beyond the invisible sea, and just the occasional tip of an unknown minaret or gigantic cypress behind the wall" (Andrić 2014a, 250).

Günter Figal suggests that "[t]he experience of space is always the experience of the confinement and expanse. Where there is too little space one feels confined, restricted [...]. The open country stands in contrast to this; that one's view does not come upon limits can be enlivening - it goes on forever, and this is like a promise" (Figal 2010, 129).

The space of the Damned Yard is not small. It is mentioned several times that it looks like a giant fair, a market-place, a huge container; nevertheless, it becomes largely closed and confined by the description, which opens the horizon in only a single direction, but expands it to infinity with the same gesture: the horizon is opened upwards, and the sky has no limits. The result is a duality of actual and transcendental phenomena: there is one single comfort in the doleful prison, and that leads towards the sky. Claustrophobia settles in.

\section{The Prison as Heterotopia and as Character}

The Damned Yard is, at the same time, an intense and unique emotional domain. It is both a place and a character, just like the bridge overarching the river Drina in the Nobel-awarded novel The Bridge on the Drina. The yard has its life, a weird and gruesome life, defined by its gallery of people, described in a dense description almost as if it were the ekphrasis of a painting by Hieronymus Bosch: 
There are both petty and hardened criminals here, from a boy who stole a bunch of grapes or a fig from a market stall to international swindlers and dangerous burglars. Some are innocent, some slandered, some feeble-minded and confused [...]. Burglars, pickpockets, professional gamblers; large-scale swindlers and blackmailers; destitute people who steal and cheat to survive; cheerful drunks who forget to pay for what they drink or tavern brawlers and trouble-makers; pale, shifty wretches who seek in addictive drugs what they have not been able to get from life, indulging in hashish, smoking or eating opium, and stopping at nothing to reach the poison they cannot live without; people with all kinds of perverse drives and habits which they do not hide or embellish, but expose for all the world to see, and even if they try to conceal them they fail, because they are apparent in everything they do. (Andrić 2014a, 244; emphasis mine)

The spatial situatedness of the yard is "vague, nameless, and foreign" (Andrić 2014a, 250), it is only the deviance of the people filling the space that is certain and manifold. The society of the yard is less hierarchical than coordinate, even in its spatiality: the detainees live a collective life and merge into a single amorphous community. Being sealed off and removed from space results in the disappearance of time; there is no other space and time, only the space and the present of the Damned Yard.

This removal turns space into a giant cell, called a devil's island by the narrator, making it no accident that the first English translation of the title was Devil's Yard (Andrić 1962). Points of spatial reference are lost, especially at night, when the place turns into something of an ancient natural formation: "One moment there will be a strange shriek, then a sigh, then, like a recitative, two or three long drawn-out words from a song, the sad and barren substitute for all kinds of sensual desires" (Andrić 2014a, 245-246).

The cell is not the ground for an individual's personal development; people are gathered in a mass during the day as well, making circles in the yard, with only one individual in the centre at a time, the actual speaker. The identity of the people is restricted to their common detainment. The narrow space gives a fertile ground for developing or growing madness.

The space becomes a character due to its particular dynamism. It is static only ostensibly. Its expansion is marked by its being a small town within the large one, Stamboul. "The prisoners from Stamboul, on top of all their other troubles, had the additional punishment of not being able to see or hear anything of their town. They were in it, but they might have been hundreds of leagues away; and that apparent distance tormented them as much as if it were real" (Andrić 2014a, 250). The yard is a vibrant, bustling flow of people, constantly in motion, always coming and going. It has its own pulsating rhythm, as if it were a living organism, 
"endlessly filling and emptying" (Andrić 2014a, 243). Some of its inhabitants stay permanently; others are only temporarily present.

Foucault describes two ways of exercising power over men in his Discipline and Punish: The Birth of the Prison (1995). One is represented by controlling lepers, the other by plague victims. He claims that all types of power are rooted in one of these forms:

The leper is caught up in a practice of rejection, of exile-enclosure; he was left to his doom in a mass among which it was useless to differentiate; those sick of the plague were caught up in a meticulous tactical partitioning in which individual differentiations were the constricting effects of a power that multiplied, articulated and subdivided itself; the great confinement on the one hand; the correct training on the other. [...] The exile of the leper and the arrest of the plague do not bring with them the same political dream. The first is that of a pure community, the second that of a disciplined society. $(1995,198)$

The community of the Damned Yard is made up of the combination of these two opposing procedures, contradictory in their nature and meaning; still it resembles more a quarantine than a prison.

Lepers and those sick of the plague - are forms of a dualistic social organization. Such a dualistic mechanism is the one that governs the flow of movements in The Damned Yard. There is a constant but unpredictable movement between the inner and the outer space, between freedom and confinement. Some are let go free, others are sent to a place to serve their sentences. But the difference between the spaces of day and night is also significant. At night the inhabitants of the yard are driven into the inner spaces and locked in cells. Closedness within confinement results in the formation of peculiar spaces, identifiable by noises: "The large cells live only through sound, like a jungle at night" (Andrić 2014a, 245). The space of the outside world, of freedom, is tangible in these moments as well. "And knocking is heard at the main entrance. For it is by night that the ancient double gate creaks and rumbles to receive or thrust out its inmates, either individually or in groups" (Andrić 2014a, 246). The system of locking and unlocking is thus doubled: it is realized both within and out of the yard.

Power is invisible, present only through the way space is segmented by surveillance, through opening and closing the doors of the cells. Although prisoners are in their cells at night, the yard hustles and bustles during the day, like a marketplace.

Closed space confines the community of the yard not merely in their acts, but also in their feelings. The mass of people lives its own life, swirls uncontrollably, and the Damned Yard is occasionally taken over by sheer madness. The wind 
blows from the south during these times, bringing a rotting smell that stinks unbearably and makes people restless. "The wind howled, seeming to spread disease everywhere. Even the most even-tempered people flared up and began roaming angrily around, looking for trouble, in a state of inexplicable aggravation" (Andrić 2014a, 251). Outbursts of anger emerge like a contagious disease, taking over the life of the entire yard: "madness, like an epidemic or swift flame, spread from cell to cell, from man to man, and was carried over from people to animals and inanimate objects" (Andrić 2014a, 251), making objects constantly fall out of one's hand. The space is filled with bodies, smell and noise. The yard becomes one giant clamour so loud that it seems almost impossible to increase the noise, with everyone hoping that at its peak it will simply explode and dissolve.

\section{Spaces of Transition}

The governor of the Damned Yard is Latif-Aga, also called Karagöz, who has gained fame by his notorious methods. Rumour depicts his character by contrasting him to the previous governor. The previous governor tried to separate sin from truth as clearly as possible, regarded the institution as quarantine, and considered the people its inhabitants. His ideas about leading the facility are in line with Foucault's description:

Generally speaking, all the authorities exercising individual control function according to a double mode; that of binary division and branding (mad/sane; dangerous/harmless; normal/abnormal); and that of coercive assignment, of differential distribution (who he is; where he must be; how he is to be characterized; how he is to be recognized; how a constant surveillance is to be exercised over him in an individual way, etc.). On the one hand, the lepers are treated as plague victims; the tactics of individualizing disciplines are imposed on the excluded; and, on the other hand, the universality of disciplinary controls makes it possible to brand the "leper" and to bring into play against him the dualistic mechanism of exclusion. (Foucault 1995, 199)

The governor considered the people of the yard dangerously ill, ones who were difficult to cure and should be kept as far as possible from the healthy and respectable world by regulations, punishment, terror, and both physical and moral confinement. "They must not be allowed to break out of their circle, but they should not be interfered with unduly, because nothing good or sensible could ever come of such contact" (Andrić 2014a, 254).

While the former governor followed the order of the "civilized world," the new one, Karagöz, flaunts his different attitude with the spatial arrangement of his life. 
He buys a property near the Damned Yard and builds his house there. It is not only the Damned Yard that belongs to heterotopic spaces, but Karagöz's property as well, as the metaphors of the text suggest, comparing the estate to an abandoned island or an ancient graveyard. It is separated from the Damned Yard by a system of fences and high walls. Its façade faces the opposite direction so that it is protected from the south wind that brings maddening restlessness and stench. Its silence and tranquillity make it the opposite of the institute. "The house had great advantage of being both very remote from the Damned Yard and very close to it. Its whole appearance, its calm and cleanliness, made it seem another world, thousands of miles away, and yet it was right next to the Courtyard, invisibly connected with it” (Andrić 2014a, 255). Karagöz's house stands next to wimpling springs, among ancient trees, in the heterotopic space of an idyllic garden, which has been the symbol of joy and the totality of the world since ancient times (Foucault 1997, 334).

Karagöz is the only one for whom the Damned Yard is a permeable space. At the same time, his own house also functions as a permeable space, thus mingling the idyllic space with that of the cell. Karagöz moves between these spaces, maintaining the double position of liminality. The connection between these two worlds is provided by another topical space: the road. There is a road leading from his house to the Damned Yard, where he goes frequently, often using shortcuts known only to him, almost living together with the detainees and the guards, supervising all of them. He works from the inside. Karagöz's whole identity is based on this ambiguity, this hybrid identity: just like in his youth, he continues to live with crime but is already beyond it. We see him in a schizophrenic state, made up of a web of infinite and undefinable contradictions, which is terrifying because of its unpredictability.

Karagöz is the personification of the prison and of power, the invisible authority that reproduces the paranoia of power through its whims and inconsistencies: "no one could ever know for certain whether he was there, or where he might suddenly appear" (Andrić 2014a, 255).

\section{The Heterotopia of the Stage}

Within the spaces of the novel we find a virtual heterotopia with multiple meanings: the Damned Yard is a stage as well, hosting a variety of psychological dramas or what may be termed a "heartless clowning" (Andrić 2014a, 258). Prisoners, once they are let out to the yard, start walking and gathering into groups. Like the others, Fra Petar is doing his rounds, but he talks to the others only individually.

The main master of ceremonies on the stage is still Latif-Aga, or Karagöz, who was named after the protagonist of the Turkish shadow theatre. He carries out his 
deeds in the spirit of the shadow theatre: he has no definite and prepared script. Improvisation is lifeblood for him, and he considers his activities a game which never repeats itself and has no routine, to the extent that he can surprise even the most experienced and best established "guests" of the yard.

With a blind and perverted passion, Karagöz walks his beat with the guards, while spreading his opinion, his main thesis being that nobody arrives at the Damned Yard by accident; nobody is innocent. "I know people; they're all guilty, only it's not written that all of them should eat their bread here. Bit-by-bit this whole monologue, spoken as he walked, grew increasingly animated, until it became a mad shout" (Andrić 2014a, 259). It ultimately becomes the fulmination of all the people in the Damned Yard, but he curses those too who are guilty but are outside of his reign. The inhabitants of the yard are convinced that he is possessed by the devil himself, or rather more than one, which is why he talks and acts this way.

Since nobody is innocent, his main goal is to extract confessions, because that is the only thing for which the guilty can be duly punished. He improvises skilfully, and his methods are boundless. He is aware of his demonic skill and does not exclude even the multiplication of his identity: "You're Armenian, in other words sly and astute, but I'm worth at least three Armenians. So why don't the four of us look for a way out of this dangerous mess" (Andrić 2014a, 265).

Karagöz is inhuman and raving, just like his methods, which he uses to make the trader to confess: he threatens him that he will spread the rumour that someone in his family has caught the plague, and consequently all of them will be quarantined in a plague hospital, where they will surely get the disease, while his empty house will be robbed in the meantime by burglars. Prisoners submit themselves to the whims of Karagöz. He is part of their lives, their identities, and they accept the rules that he introduces on the stage of the Damned Yard.

\section{Spatial Doubles and Identity Bifurcations}

It becomes gradually clear in the text that the space specificities do not only concern actual spatial relations but the modes of the narrative as well: it is made up of a chain of interlinked heterotopias. The first pages reveal the heterotopic space of a cemetery. The text begins with the description of the graveyard enveloped by snow: the young narrator, who remains in the background, can see the grave of Fra Petar through the window.

A certain kind of dichotomy, created by elements that may be understood as alter ego, bifurcation of the self or schizophrenia, is a recurring element in the novel, appearing not only as the contradictions of outside/inside, down/above, real/imaginary, but also the fact that everything comes in sets of two. 
This dichotomy and layeredness appear already in the opening image, the graveyard that disappeared under the snow. The landscape that we see in this sense hides another world, depriving everything of its "real form," and the description lifts everything from real ground, making it hover in mystery. The whiteness of the external world blends with the shadowy cell of the deceased Franciscan monk, blurring outside and inside spaces. There are two people taking inventory in the cell, who also have double identities. They are not mere inventory makers; they are pillagers, burglars of a life's memories. The narrator is fixated on creating two of everything, which presupposes a pathological soul. This "manic" atmosphere determines the development of text itself, that is the narrator also doubles throughout the text. The reader has the feeling that the number of perspectives is also constantly growing. Madness as a central organizing principle is defined through a crucial Nietzschean paragraph that focuses on the self. It is bracketed, as if it did not fit in the plot, while as an element of spatial poetics it has a crucial position and role: it points out that the soul has a space of its own, with the self in the centre, defining itself as indecipherable and unintelligible. Behind every act there is another mind, which "controls" and supervises itself.

The "young man" in the background evokes the figure of Fra Petar, who remembers his two months spent in the Damned Yard, primarily its "interesting, comic, pathetic, deranged" (Andrić 2014a, 267) people. Fra Petar also arrives in Stamboul as one of two people, with Fra Tadija, who can only speak, but not write or read Turkish.

Next to the heterotopic prison of the Damned Yard there is the heterotopic garden of Karagöz, with a road joining and likening the two. Karagöz too is someone with a deranged mind. He is a criminal and an investigator at the same time but can make people believe that there are several others in the spectrum of his identities.

Roads are created among the walls by the routes trodden by the inhabitants, including Fra Petar during his conversations. He has two partners to talk to, first Zaim, then Haim. He speaks to them one by one, but it is impossible to miss the similarity between the two. Even their names differ only by a single letter. They seem to be each other's opposite twins. Zaim is an eccentric monomaniac whose only topic in conversation is himself, while Haim is quite the opposite: he tries to identify with others, preferably with people who are more refined and belong to a higher stratum of the social hierarchy.

Ancestry and belonging have a significant role in the novel. Fra Petar's third conversation partner is the learned Kamil. His story too abounds in heterotopic and dualistic elements. Foucault regards the ship as a heterotopic space par excellence, "a floating part of space, a placeless place, that lives by itself, closed in on itself" $(1997,336)$. The tragic fate of Kamil's mother is sealed by a sea journey. When her daughter dies, the ship becomes a graveyard. The captain, to 
temper her grief, secretly has two coffins made. The one with the child's body is lowered into the water, while the mother takes and puts to eternal rest the other coffin at home. Later, however, it turns out that she buried an empty coffin, which drives her mad. Following a mirror-like structure in the narrative, the Greek woman then marries a Turk, and Kamil is their child, who dedicates his life to studying history, because he is not allowed to marry the Greek woman whom he fell in love with. Kamil's identity is defined throughout by the fact that he is a great admirer of Sultan Beyazit's brother Cem-Sultan, with whom he happily identifies. "Kamil confessed openly and proudly that he was the same as Cem-Sultan" (Andrić 2014a, 325). Kamil finds himself in between two worlds in double sense: between his own and Cem-Sultan's self, and also between Greek and Turkish identity. "He seemed both like a Turk and not, but it was certain that he was an unhappy man," says the narrator about him (Andrić 2014a, 275).

The links between heterotopic spaces and narrators bring us towards a virtual centre in the narrative, which can be represented in the following way: Young man - Fra Petar - Zaim - Haim - (Kamil - Cem) - Haim - Zaim - Young man. The young man who appears at the beginning of the novel, the unidentified narrator, remembers Fra Petar's story, who meets Zaim first, then Haim. Haim tells him the story of Kamil, with whom he will speak almost entirely about prince Cem. In the middle of the plot Kamil surrenders his identity completely, recites the poems of prince Cem, and it is Cem-Sultan who speaks through him. Later, when Kamil disappears, as a result of Karagöz's interrogation, Haim tells the story about what he supposes may have happened to him:

If he was alive, they had probably taken him to the Timarkhane, near the Suleymaniye, where mental patients were locked up. There, among lunatics, his stories about himself as heir to the throne would be the same as all the words of madmen, the innocuous ravings of the ill to which no one paid any attention. And such a deranged, sick person did not in any case live long but slipped quickly and easily out of the world, together with his morbid imaginings, without anyone having to account to anyone for it. (Andrić 2014a, 327)

Next, Zaim's stories lead Fra Petar out of the plot. The layeredness of the narrative contributes to the experience of space. All levels have to be visited twice, first inward, towards the centre of the plot, then again, this time outward. The narrative goes increasingly deeper towards madness which is the result of a lost identity, only to waken us and lead us back to higher levels of identification.

All characters in the novel bring their own madness from the outside world into the Damned Yard, which then adds its own influence. Fra Petar is the only one who goes through a significant change. Initially his calm stands out from the bustling, tumultuous mass. The fact that the Christian monk from Bosnia 
becomes so intrigued by the fate of the Turkish young man from Smyrna is explicable only by some extraordinary circumstance. However, with Kamil's disappearance Fra Petar's stable identity is shaken. When he realizes that after talking to Kamil he cannot stop continuing the dialogue and keeps speaking to himself, he understands that something broke inside him.

Why, I'd been talking to myself! I was afraid of madness as of an infectious disease and of the thought that in this place with time even the sanest man starts seeing things. And I began to resist. I defended myself, forced myself to remember who and what I was, where I had come from and how I came here. I reminded myself that apart from this Courtyard there was another, different world, that this was not all there was and it was not forever. And I endeavored not to forget this, to hold on to this idea. But the Courtyard was like a whirlpool dragging a man into its dark depths. (Andrić 2014a, 338)

It is not the uncontrollable Karagöz, but rather the Damned Yard that breaks people, making even the healthy fall ill. It is a closed space, set off from the rest of the world, a place where everyone thinks all corners are under surveillance. There is a supposed, invisible authority, an eye that sees all. This is what drives people mad. The yard's power gets everyone, even the innocent, even those who resist, because they are aware of its power which drags one down. "He forgot what had happened before and thought less and less of what was going to be, so that past and future merged in one single present, the strange, terrible life of the Damned Yard" (Andrić 2014a, 250). Even Fra Petar turns out not the person he seems to be at the first glance. He becomes the prisoner of the yard. And the yard stays with him even when he leaves, in his exile. "It was going with him on his journey and it would accompany him, awake and asleep, throughout his stay in Acre, and afterwards" (Andrić 2014a, 341), until the end of his life.

\section{The "Deranged" Narrative}

The novel displays significant metatextual references. From time to time the voice of an omniscient narrator is heard, that of someone who is beyond the events, who is not identical to any of the narrators mentioned so far, and who makes remarks about the nature of narration. Most often, scholars identify this position with the writer's. But similar comments are made by the young man who frames the plot, and occasionally by Fra Petar as well, who halts the story with his self-reflexive musings.

This is how narrators are formed in front of our eyes. The narration follows the world of the novel, since the text created by a deranged mind will be similarly 
"deranged," but each narrator is deranged in his own way. Zaim, who speaks exclusively about himself, lies continuously, but his eyes go frantically to and fro, and incessant talk is a mere compensation for him, with which he manages to keep his mind temporarily away from what genuinely interests him: the punishment that awaits him. His stories, which stretch infinitely, are exaggerated, hyperbolic, and disregard norms.

Haim feels the need to talk all the time. He is verbose, talks nonsense, can never focus, but is brilliant in impersonating others. The omniscient narrator regards his text as far from flawless, and makes corrections to it. "That was Kamil Effendi's story, the way Haim was able to know and envisage it. It has been related here briefly, without Haim's repetitions and comments and his numerous cries of 'Eh? Ah!”' (Andrić 2014a, 291). But he speaks on his behalf as well:

For, what would we know about other people's souls and thoughts, about other people and consequently about ourselves, about other places and regions we have never seen nor will have the opportunity of seeing, if there were not people like this who have the need to describe in speech of writing what they have seen and heard, and what they have experienced or thought in that connection? Little, very little. (Andrić 2014a, 279-280)

The complete dissolution of the self is exemplified in Kamil, who identifies himself entirely with the story of another person.

Fra Petar creates a "deranged" narrative in the sense that he uses the logic of empty spaces, blanks that need to be filled by the reader: "These fragments did not always follow one from another in proper order. [...] His tale could stop, go on, repeat itself, anticipate, go back, and, once it was ended, be added to, explained and expanded, regardless of place, time and the real, forever established course of events" (Andrić 2014a, 242).

The only narrator in the story who can retain his calm and wisdom is the young narrator in the frame. The metatextual level of the novel, thus, suggests the central idea that in spite of the world's madness there is a central narrative consciousness which remains unscathed, and which is capable of letting the story out from the whirling fantasy world of madness to the sober ground of reality.

\section{Conclusion}

In the novel Haim voices his verdict on the crowd of the yard: "there's not a single man in his right mind here. Believe me! They're all crazy, the guards and the prisoners and the spies (and almost all of them are spies!) not to mention the 
greatest madman, Karagöz. In every other country in the world he'd have been locked up in a madhouse long ago" (Andrić 2014a, 339).

The idea of overall madness is not alien to Andrić's other works either, but his attitude towards his characters who have deranged minds is always characterized by compassion, a combination of humour and pity. His Bosnian stories, for example, "The Story of the Vizier's Elephant” (Andrić 2014b), certainly belongs to this group. His novels with different themes also evoke the same attitude. In his brilliant "Bar Titanic" (Andrić 1969), depicting a story from the Second World War, the loony Jewish tavern-keeper has his own personal Ustasha. Both of them are genuine Andrić-characters, who feel that they are not in their rightful place, and who deserved better. The Ustasha is not a real slaughterer but would like to become one in order to retain his status, while the Jewish man is not a real Jew because he lacks money. At the end of the story, the Ustasha is shooting randomly while the tavern-keeper is skipping to and fro to avoid the bullets - as if they lived in perfect harmony with one another and were in peace with their fate and the world.

The Damned Yard is not like that. Humorous moments are absent from it. Andrić's characters live in this world as if they were outside of everything, and the inevitability of their fall looms over them with certainty, but they simply do not know when, where and why disaster will befall them. Local stories tend towards the absurd.

Contemporary interpreters saw a new Franz Kafka phenomenon from the Balkans in him (Bori 1992). The lack of freedom, the idea of committing crime, sacrifice, guilt and the fact that truth is out of reach - all these, projected into the past, make up the philosophical basis of the novel. However, the opposite interpretation is relevant as well, the one that reads "forward," and considers the Damned Yard the prefiguration of the Gulag, identifying it with totalitarian regimes in general.

Andrić scholars see the influence of the Renaissance historian and writer, Guicciardini, in the way Andrić depicts rotation in history (Bori 1992). And he so consistently does it that it surfaces in all his aspects, spaces and narrative techniques. The Damned Yard does not have small, rectangular, closed cells and spaces; movements in it are circular, and at a metaphorical level this circularity permeates the text: "At such times this whole Courtyard moaned and clattered like an enormous rattle in a giant's hand while the people in it danced, jerked, knocked into one another and beat against the walls like grains in the rattle" (Andrić 2014a, 251-252). The Damned Yard is given metaphysical dimensions and becomes a universal metaphor for existence: it becomes the space of existential defencelessness. 


\section{Works Cited}

Andrić, Ivo. 1969. "Bar Titanic." In The Pasha's Concubine and Other Tales. Trans. Joseph Hitrec, 251-289. London: G. Allen and Unwin.

Andrić, Ivo. 2014a. "The Damned Yard. Trans. Celia Hawkesworth.” In The Damned Yard and Other Stories, ed. Celia Hawkesworth, 239-344. Beograd: Dereta.

Andrić, Ivo. 2014b. “The Story of the Vizier’s Elephant.” Trans. Celia Hawkesworth. In The Damned Yard and Other Stories, ed. Celia Hawkesworth, 23-78. Beograd: Dereta.

Bokonjić, Risto. 1981. "Analiza jednog ludila u Andrićevom djelu." [“The Analysis of Madness in Andrić's Novel.”] In Delo Ive Andrića u kontekstu evropske književnosti i kulture: Zbornik radova sa međunarodnog naučnog skupa održanog u Beogradu od 26. do 29. maja 1980 [Ivo Andrićs Oeuvre in the Context of European Literature and Culture: Collection of Works Presented at the International Symposium in Belgrade, May 26-29, 1980], ed. Dragan Nedeljković, 601-611. Beograd: Zadužbina Ive Andrića.

Bori, Imre. 1992. Ivo Andrić. Novi Sad: Forum.

Dor, Milo. 2002. "Nachwort." In Der verdammte Hof, Ivo Andrić, trans. Milo Dor and Reinhard Federmann, 157-165. Frankfurt am Main: Suhrkamp.

Džadžić, Petar. 1975. O Prokletoj avliji. [On The Damned Yard.] Beograd: Prosveta. Đukić Perišić, Žaneta. 2012. Pisac i priča. Stvaralačka biografija Ive Andrića. [The Writer and the Story. Literary Biography of Ivo Andrić.] Novi Sad: Akademska knjiga.

Figal, Günter. 2010. Objectivity: The Hermeneutical and Philosophy. New York: SUNY Press.

Foucault, Michel. 1995. Discipline and Punish: The Birth of the Prison. Trans. Alan Sheridan. New York: Vintage Books.

Foucault, Michel. 1997. "Of Other Spaces: Utopias and Heterotopias." In Rethinking Architecture: A Reader in Cultural Theory, ed. Neil Leach, 330336. New York: Routledge.

Kermauner, Taras. 1979. "Otvorenost, zatvor, ludilo." [“Openness, Prison, Madness."] In Zbornik radova o Ivi Andriću [Collection of Works on Ivo Andrić], ed. Antonije Isaković, 601-635. Beograd: Srpska akademija nauka i umetnosti.

Klevernić, Ljiljana, Kata Mirić, Melanija Blašković, Vesna Ukropina, Daniela Kermeci, Slađana Subašić and Marija Vaš. 2011. Bibliography of Ivo Andrić (1911-2011). Belgrade-Novi Sad: Ivo Andrić Foundation - Serbian Academy of Sciences and Arts - Matica Srpska Library.

Kostić, Dragomir. 2006. Andrić, Prokleta avlija. [Andrić, The Damned Yard.] Novi Sad: Svetovi. 
Márton, László. 2007. "Regény a helyszínről.” [“A Novel about Locale.”] Jelenkor vol. 50 no. 1: 70-76.

Minić, Vojislav. 1976. Poetika "Proklete avlije". [The Poetics of The Damned Yard.] Titograd: Pobjeda.

Thomka, Beáta. 2009. "Topográfia és retorika.” [“Topography and Rhetorics.”] In Déli témák: Kultúrák között [Southern Themes: In-between Cultures], 53-68. Zenta: zEtna.

Vukićević-Janković, Vesna. 2015. "Prostorska semantika Prekletega dvorišča." ["Spatial Semantics of The Damned Yard."] Slavistična revija vol. 63 no. 3: 311-318. 